\section{5. 日本举法の特得}

大阪葶英女子短期大学 沢 山 勝

大阪市立大学土谷秀雄

日本笔法は，拳の笑打と踣，また組みついた場合の投 技や管技を綜合した徒手の格技であるが，その特質とし て他の拳技と異るとことろは，奉足の突，打，尉に対 し，双方が防具を着装して，自由に整合い，乙かも安全 に管古をし，また試合をするところである。

このような拳足の技と投技や赛技とを綜合した格技は 古代からあつたようである．たと党ば，わが国の古代相 撲である. 垂仁天皇の御代に大和の禁庭で行われた野見 宿唃と当麻跮速との「すまい」とか，西欧では，古代ボ クシングのブギリズム (Pugilism) とレスリングを合体 させだ゚ンクラチオン (Panklation)が，この格技とな る.だが，この種の格技は極わめて佶険であり，試合な どすると必す死傷者がでたとのことである.

これでは，とても今日のスポーツとして，また体育の 教材とするわけにはゆかない，従来，笔法は型や独り稿 古をしてきたるのである.だがこれでは，とらてい充 分な練成効果を収めることはできない。

そこで，面，胴（外胴と胴下当），股当，手袋を作り， 防具着装の稭古を創案したのである.多少は防具の制約
を受けても，安全性が稽古を自由自在にする。これが技 術攸練に大きな効果を与る. 自由自在汢人間本来の技能 と個性とを呼びおこす，そして，技術形成の身体運動を (1) 身体の構造機能飞即合せしめ, (2) 力学的, (3) 兵法 （钱術）的にする.この事実. すなわち, 防具䅋古の安 全性が技術修練に大きく効果をもたらすことは，すでに 日本剣道が実証している。

いままで試みられなかつた全法の防具化をなしとげた のはわれわれ日本人である. 日本奉法の名称も，この特

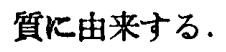

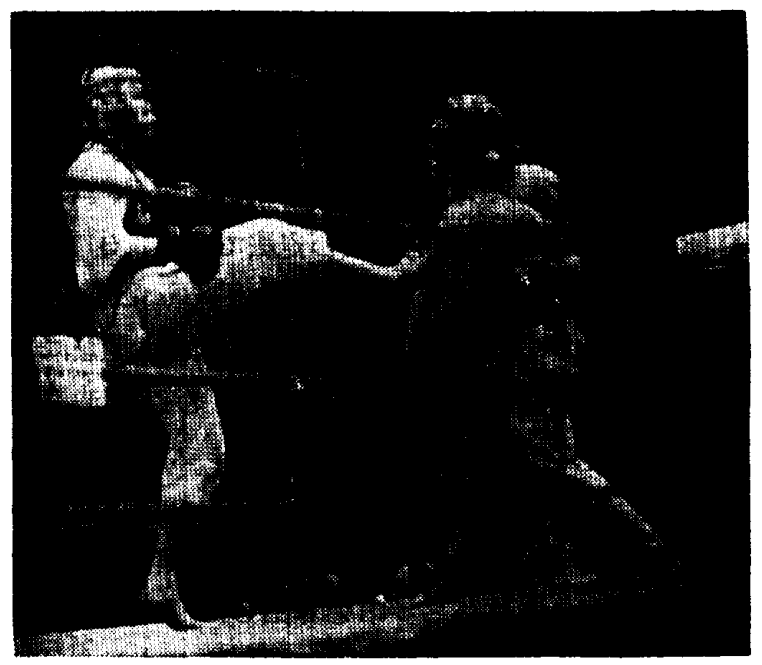

136.レクリエーションスポーツ受好著に阴する考富

尃大学○渡部 峇生, 長島 博

清水 瑞秋

\section{1. 研究の目的}

$\begin{array}{lll}\text { 武蔵野女子大学 } & \text { 松 島 宏 } \\ \text { 武蔵野工業大学 } & \text { 古 賀 } & \text { 郎 }\end{array}$

近年レクリエーションスポーツ愛好者が增大して来 た. 特に戦後の我が国に移入されたそれらスポーツの発 展は目を見はるあのがある.しかしながら，それらスポ 一ツの普及と発展，スポーツ人口の增加，などに伴う多 くの問題も生れて来ている, レクリエーションスポーツ 赏好者が，各自の愛好するスポーツをどのように考えて いるか，それと其汇他のスポーッと，どのよらに対比し ているかといら方向から，それら問題点を明らかにして みようと考えた、今回は、ボーリング愛好者を中心に調 㭗した結果を発表する。

\section{2. 問题の設定}

（イ）ボーリングに対する考え力

（口）ボーリング愛好者の他スポーツへの孝え方

\section{3. 閒查の手つつき}

期日 調查 I 昭和42年 6 月

II昭和42件 9 月 1011

㑥防 柬京フェアレーンズ

清田スターレーン

\section{対象 一般男女・大学生 (学連加盟校)}

\section{4. 結果の考実}

（イ）関しては，男女共にボーリングが気分転换とス トレス解消などを目的として楽しんでいる様にみられ， 同時に大げさな準価を要せず，しかも老若男女が手軽に 出来るといら魅力を感じていると思われる，ボーリング に関しては少くとも私の調查結果からは健康䊒持を目的 とする以上に他の要素, つまり, 前記の他のスポーツに ない諸点が覆好者をひきつけているよらに考光られる。 ヌボーリングの運動量などの点では，運動が自己の体力 に適しているといいながらも，量の問題となると，若年 層のみならず高年令層でも不足であると答えている。こ れなども今後の課題として残るるのであろう。これに関 連して，(口)の項については，ボーリングが戸外運動 でないせいもあるといらものの，広いグランドで精一杯 動き廷りたいという欲望はかなりの高いるのと推定され る結果が出ている。他のスポーツへの無関心者には体力 に自信なしとするものが多い。

同時に調查した大学の運動部としてのボーリング活動 は，一般とかなり違つた点がみられる．即ち一般の方は あくまで楽しみが主であるのに対して，精神面にかなり 重点を笡いている. 動機の調查でも精神集中がかなりの 滈いハーセンテージをあげているのもそれであろら。

総しててみると、ボーリングは老人も若い者にも男女の

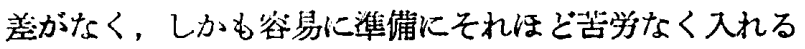
ことが大きな要素となつて管好されている。 